\title{
ANALISIS KEMAMPUAN BERFIKIR KREATIF MATEMATIS SISWA DALAM MENYELESAIKAN SOAL PEMECAHAN MASALAH
}

\author{
${ }^{1}$ Yayah Huliatunisa, ${ }^{2}$ Elang Wibisana, ${ }^{3}$ Lensi Hariyani \\ Universitas Muhammadiyah Tangerang \\ yhuliatunisa13@gmail.com
}

\begin{abstract}
Abstrak
Penelitian iniuntuk menganalisis tingkatkemampuan berfikirkrea tif matemat is sis wa dalam pemecahan masalah soalcerita materi operasi hitung pecahan, menggunakan 5 penjenjangan tingkat berfikir kreatif te ori Siswono ; 4/sangat kreatif, 3/kreatif, 2/cukup kreatif, 1/kurang kreatif dan 0/tidak kreatif, den gan in dikator berfikir krea tifnya ; lancar/fluency, luwes/flexibility, orisinil/originaly, terperin ci/elabo ra tor. Ku ran gnya motivasi belajar siswa berdampak rendah dan menghambat berkembangnya kemampuan berfikir kreatif, siswa cenderung pasif, tidak ingin bertanya dalam proses pembelajaran bahkan mala s untuk menyelesaikan masalah secara mandiri. Solusi 1) guru hendaknya mampu menganalisis faktor penyebab nya, 2) tanamkan ke pada siswa sifat untuk mampu memotivasi dirinya sendiri melalui pemberian latihan soal untuk bertujuan menggali kemampuan yang mungkin belum muncul. Kesimpulan; tingkat kreatifitas paling tin ggi a dalah kreatifitas tingkat 3/kreatif dengan mampu menunjukkan kefasihan, kebaruan/kefasihan dan fleksibilitas, siswa berkemampuan sedang mencapai kreatifitas tingkat 2 /cukup kreatif dengan mampu menunjukkan kebaruan/fleksibilita s, sedangkan siswa berkemampuan rendah/kurang mencapai kreatifitas tingkat $1 /$ kurang kreatif yang hanya mampu menggunakan kefasihan saja.
\end{abstract}

Kata kunci : Kreatifitas, Berfikir kreatif matematis, Menyelesaikan soal.

\begin{abstract}
This study wa s to a nalyze the level of mathematical creative thinking ability of student in problem solving material in ca lculating fraction operations, using 5 levels of Siswono's theory of creative thin king; 4/very creative, 3 /creative, 2 /quite creative, $1 /$ less creative and $0 /$ not creative, with indicators of creative think ing ; fluent/fluency, flexible/flexibility, origina//originaly, detailed/elaborator. Lack of sudent motivation to have a low impact and inhibit the development of creative thinking a bilities, students tend to be passive, do not wa nt to a sk questions in the lea rning process even la zy to solve problems independently. Solution 1) the teacher should be able to analyze the causative factors, 2) instill in students the $n$ at ure of being a ble to m otiv ate themselves through the provision of excercises to aim at exploring abilities that may not yet appear. Conclusion; the highest level of creativity is level 3/creative creativity by being able to show fluency, novelty/fluency and flexibility, capable students are reaching level 2 crea tivity/quite creative by being able to show novelty/flexibility, while students with low ability/lack of level 1/less creativity creative who is only able to use fluency a lone.
\end{abstract}

Keywords; Creativity, Mathematical crea tive thinking, Solving problems.

\section{PENDAHULUAN}

Pendidikan merupakan proses yang hasilnya menghendaki perubahan dan pendewasaan diri. Pendidikan menjadi kebutuhan yang tidak terbantahkan sebagai sarana mengembangkan sumber daya manusia untuk memiliki kemampuan dan kecerdasan berpikir logis, kritis, kreatif, inisiatif dan adaptif terhadap pertumbuhan dan perkembangan zaman di setiap fase kehidupannya. Sehingga setiap manusia dituntut untuk dapat memenuhinya sedini mungkin melalui berbagai upaya, seperti bagaimana seorang siswa dilatih untuk mengembangkan kemampuan berpikir dan memecahkan masalah melalui mata pelajaran matematika dijenjang sekolah dasar. Pemecahan masalah yang telah 
dirancang baik, meliputi pemilihan tehnik dan strategi yang tepat, di harapkan dapat memberikan kesempatan untuk tumbuhnya berbagai keterampilan dan memunculkan kemampuan-kemampuan yang sebelumnya mungkin belum tampak pada siswa.

Menurut Permendiknas RI No. 19 tahun 2005 tentang Standar Nasional Pendidikan pasal 1 No. 14, pendidikan dalam mata pelajaran matematika bertujuan agar siswa memiliki kemampuan sebagai berikut:

1. Memahami konsep matematika, menjelaskan keterkaitan antar konsep dan mengaplikasikan konsep atau algoritma, secara luwes, akurat, efisien, dan tepat, dalam pemecahan masalah.

2. Menggunakan penalaran pada pola dan sifat, melakukan manipulasi matematika dalam membuat generalisasi, menyusun bukti, atau menjelaskan gagasan dan pernyataan matematika

3. Memecahkan masalah yang meliputi kemampuan memahami masalah, merancang model matematika, menyelesaikan model dan menafsirkan solusi yang diperoleh

4. Mengomunikasikan gagasan dengan simbol, tabel, diagram, atau media lain untuk memperjelas keadaan atau masalah

5. Memiliki sikap menghargai kegunaan matematika dalam kehidupan, yaitu memiliki rasa ingin tahu, perhatian, dan minat dalam mempelajari matematika, serta sikap ulet dan percaya diri dalam pemecahan masalah.

Kemampuan merupakan suatu tindakan yang dapat dilakukan seseorang sesuai dengan tingkat pengetahuan, penalaran, dan lainnya yang berkaitan dengan kehidupan masyarakat, yang secara keseluruhan dapat diperoleh dari beragam pengalaman atau tindakan. Kemampuan sejatinya telah ada dalam setiap diri manusia dari sejak lahir, sehingga hanya butuh cara dan strategi bagaimana setiap kemampuan yang beragam tersebut dapat dikembangkan sesuai dengan taraf kemampuannya. Sebagaimana dikatakan Munandar (2017) kemampuan merupakan daya untuk melakukan suatu tindakan sebagai hasil dari pembawaan dan latihan.

Berpikir kreatif merupakan pemikiran yang bersifat keaslian, reflektif dan menghasilkan suatu produk yang kompleks dalam permasalahan matematika. Berpikir tersebut melibatkan sintesis ide-ide, membangun ide-ide baru dan menentukan efektivitasnya. Selain itu, berpikir kreatif juga berkaitan dengan kemampuan untuk membuat keputusan dan menghasilkan produk yang baru. Coon \& Mitterer (2014) yang 


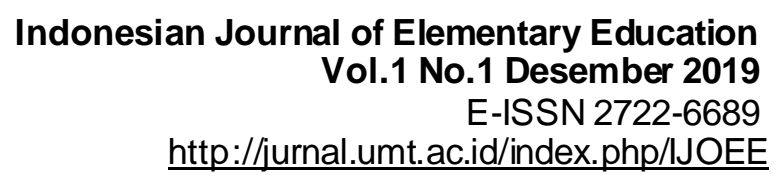

mengungkapkan bahwa berpikir kreatif atau kreativitas merupakan aktivitas memecahkan masalah yang dilakukan melalui proses eksperiensial secara tidak sadar di dalamnya tercakup pula kelancaran dalam menghasilkan sejumlah ide, keluwesan menggunakan waktu dalam menghasilkan beragam jenis solusi, dan kebaruan ide atau solusi yang dihasilkan. Pelajar yang mampu berpikir kreatif akan mempunyai ide-ide (daya cipta) untuk menyelesaikan berbagai persoalan. Setiap pelajar harus berlatih berpikir kreatif untuk menjadi pelajar yang produktif, Sun (2011). Pengertian ini menunjukkan bahwa berpikir kreatif adalah suatu aktivitas kemampuan dalam mengungkapkan atau memecahkan masalah untuk menghasilkan dan menciptakan ide-ide yang baru dari konsep yang sudah dikuasai sebelumnya.

Indikator kemampuan berpikir kreatif dalam pelajaran matematika menurut Munandar (2017) terdapat 4 komponen yaitu, Berpikir Lancar (Fluency): Mencetuskan banyak jawaban, gagasan, dan penyelesaian masalah, Berpikir Luwes (Flexibility): Menghasilkan gagasan atau jawaban yang bervariasi, Berpikir Orisinil (Originality): Mampu memodifikasi atau membuat kombinasi baru dari bagian-bagian atau unsur-unsur dan Berpikir Terperinci (Elaboration): Menambahkan atau memperinci detail-detail dari suatu objek, gagasan atau situasi sehingga menjadi lebih baik.

Siswono (2018) mengembangkan level penjenjangan Tingkat berpikir kreatif ini terdiri dari lima tingkatan yaitu ; tingkat berpikir kreatif 4 (sangat kreatif), tingkat berpikir 3 (kreatif), tingkat berpikir 2 (cukup kreatif), tingkat berpikir kreatif 1 (kurang kreatif), dan tingkat berpikir kreatif 0 (tidak kreatif).

Tabel 1. Tingkat Berpikir Kreatif Matematis (TBKM)

\begin{tabular}{ll}
\hline \multicolumn{1}{c}{ Tingkat Berpikir Kreatif Matematis } & \multicolumn{1}{c}{ Karakteristik } \\
\hline Tingkat 4 (sangat kreatif) & Peserta didik mampu \\
& menunjukkan, fleksibilitas, \\
& dan kebaruan dalam \\
& memecahkan maupun \\
& mengajukan masalah \\
\hline Tingkat 3 (kreatif) & Peserta didik mampu \\
& menunjukkan kefasihan dan \\
& kebaruan atau kefasihan dan \\
& fleksibilitas dalam \\
& memecahkan maupun \\
& mengajukan masalah \\
\hline
\end{tabular}




\begin{tabular}{ll}
\hline Tingkat 2 (cukup kreatif) & Peserta didik mampu \\
& menunjukkan kebaruan atau \\
& fleksibilitas dalam \\
& memecahkan maupun \\
& mengajukan masalah \\
\hline Tingkat 1 (kurang kreatif) & Peserta didik mampu \\
& menunjukkan kefasihan \\
& dalam memecahkan maupun \\
& mengajukan masalah \\
\hline Tingkat 0 (tidak kreatif) & Peserta didik tidak mampu \\
& menunjukkan ketiga aspek \\
& indikator berpikir kreatif \\
\hline
\end{tabular}

Mairing (2018) mengatakan bahwa pemecahan masalah adalah sebagai proses berpikir yang diarahkan untuk memperoleh jawaban dari masalah. Berpikir adalah suatu proses sehingga pemecahan masalah dapat dipandang sebagai suatu proses. Dengan demikian proses siswa dalam memperoleh jawaban dalam pemecahan masalah lebih diperhatikan dibandingkan dengan jawabannya.

Kemampuan berpikir kreatif matematis adalah kesanggupan seseorang dalam melakukan suatu tindakan untuk meningkatkan potensi yang dimilikinya berdasarkan kombinasi 2 perangkat faktor kemampuan yakni kemampuan intelektual yang mengarah pada mental untuk berpikir, menalar dan memecahkan masalah serta kemampuan fisik yang lebih mengarah kepada tugas-tugas yang menuntut stamina, keterampilan, kekuatan dan karakteristik yang serupa, keduanya digunakan ketika individu memunculkan suatu ide baru, di mana ide tersebut merupakan hasil dari tingkat berpikir kreatifnya yang dirancang dalam pemikirannya sendiri. Manfaat dari kemampuan berpikir kreatif matematis akan memunculkan ide-ide baru atau gagasan spontan dan terkadang tanpa direncanakan sebelumnya dalam pemikiran individu, sehingga akan mendatangkan pemikiran dan jawaban kreatif dan bervariasi pada setiap persoalan yang dihadapi. Indikasi dari berpikir kreatifnya yaitu produk aktivitas mental yang mempunyai sifat kebaruan dan bernilai baik secara subjektif dan objektif, proses berpikirny a ju ga baru, artinya memerlukan suatu transformasi ide-ide yang diterima maupun ditolak sebelumnya, serta proses berpikir yang di karakteristik kan oleh adanya motivasi kuat dan stabil, teramati pada periode waktu yang lama atau dengan tingkat intensitas tinggi. Sehingga dengan kemampuan berpikir kreatif matematis ini di harapkan individu dapat mampu memecahkan masalah dengan cara menemukan kombinasi atau mendapatkan 
pemikiran yang lebih terperinci dari sejumlah aturan yang dapat diterapkan dalam upaya mengatasi situasi baru yang ditemuinya, dengan beberapa strategi yang dapat digunakan, seperti mengorganisasi data dalam bentuk tabel, menduga dengan cerdas dan menguji secara kontinu, mulai menyelesaikan masalah dari yang sederhana dan relevan, melakukan simulasi kondisi pada masalah nyata, melakukan strategi melalui penalaran logis dan lainnya, dan secara keseluruhan dilakukan secara rutin, memilih prosedur tepat, mereduksi permasalahan nyata, dan evaluasi berkala.

Penelitian ini bertujuan untuk menganalisis tingkat kemampuan berpikir kreatif matematis siswa dalam pemecahan masalah soal cerita pada materi operasi hitung pecahan pada siswa kelas V SDN Kosambi 1 Kabupaten Tangerang, menggunakan 5 level penjenjangan tingkat berpikir kreatif teori Siswono dengan didasarkan pada indikator berpikir kreatif teori Munandar, setelah ditemukan beberapa permasalahan pada saat observasi awal di objek penelitian, seperti kurangnya motivasi siswa yang berdampak kepada rendah dan menghambat berkembangnya kemampuan berpikir kreatif, siswa lebih cenderung pasif, tidak ada minat untuk bertanya pada saat proses pembelajaran, jika tidak dibimbing guru siswa cenderung malas untuk menyelesaikan masalahnya secara mandiri, siswa selalu menganggap contoh soal lebih mudah dibandingkan latihan soal yang diberikan guru yang berdampak siswa terus bertanya bagaimana cara menyelesaikan dan memecahkan masalah tersebut tanpa adanya keinginan untuk mencoba menyelesaikan secara mandiri meskipun dengan cara dan jawaban yang beragam. Kurangnya stimulus guru juga berdampak siswa malas untuk mencari jawaban dengan cara berbeda tanpa harus mengikuti contoh yang diberikan.

\section{METODE PENELITIAN}

Penelitian kualitatif ini menggunakan metode penelitian deskriptif yang berlandaskan filosofis postpositivisme. Data yang dikumpulkan berkemungkinan menjadi kunci terhadap apa yang sudah diteliti. Laporan penelitian ini berisi kutipan-kutipan data untuk memberi gambaran penyajian. Data tersebut berasal dari naskah wawancara, catatan lapangan, foto, dokumen pribadi, catatan atau memo, dokumen resmi lainnya dan hasil tes kemampuan berpikir kreatif siswa kelas V SDN Kosambi 1 Kabupaten Tangerang. Tingkat pencapaian kemampuan berpikir kreatif penelitian ini didasarkan pada 4 komponen teori Munandar yaitu, Berpikir Lancar (Fluency): Mencetuskan 


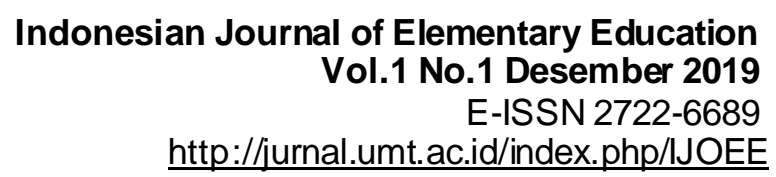

banyak jawaban, gagasan, dan penyelesaian masalah, Berpikir Luwes (Flexibility): Menghasilkan gagasan atau jawaban yang bervariasi, Berpikir Orisinil (Originality): Mampu memodifikasi atau membuat kombinasi baru dari bagian-bagian atau unsurunsur dan Berpikir Terperinci (Elaboration): Menambahkan atau memperinci detaildetail dari suatu objek, gagasan atau situasi sehingga menjadi lebih baik, dan teori Siswono (2018) terkait pengembangkan 5 level penjenjangan Tingkat berpikir kreatif yaitu ; tingkat berpikir kreatif 4 (sangat kreatif), tingkat berpikir 3 (kreatif), tingkat berpikir 2 (cukup kreatif), tingkat berpikir kreatif 1 (kurang kreatif), dan tingkat berpikir kreatif 0 (tidak kreatif).

Tehnik analisis data yang digunakan mengadopsi dan mengembangkan teori dari Miles dan Hubberman, meliputi ; reduksi data, menyajikan data, dan menarik kesimpulan. Setelah data dianalisis sampai ditemukan jawaban dari pertanyaan penelitian, selanjutnya dilakukan pengecekan kevalidan atau keabsahan data dari hasil temuan dengan triangulasi tehnik.

\section{HASIL DAN PEMBAHASAN}

Berdasarkan analisis kemampuan berpikir kreatif, subjek meliputi hasil tes kemampuan berpikir kreatif dalam menyelesaikan soal pemecahan masalah, observasi, dan hasil wawancara akan dijadikan acuan untuk mengambil perwakilan setiap anak dalam tingkatan berpikir kreatif matematis. Hasil penelitian menunjukkan dari 34 siswa diambil 6 subjek yang menjadi perwakilan tingkat berpikir kreatif dari tingkat kurang kreatif sampai tingkat sangat kreatif. Berikut hasil analisis kemampuan berpikir kreatif matematis siswa berdasarkan tingkat kemampuannya;

Hasil analisis kemampuan berpikir kreatif matematis siswa yang mempunyai tingkat kemampuan tinggi yaitu subjek inisial (KS dan NC) berada pada TBKM level 3 (kreatif), kemampuan sedang yaitu subjek inisial (AFR dan SIL) berada pada TBKM level 2 (cukup kreatif), dan kemampuan kurang yaitu subjek inisial (MH dan NAA) berada pada TBKM level 1 (Kurang kreatif).

Secara umum indikator berpikir lancar (fluency) telah terpenuhi oleh ke enam subjek yaitu (subjek KS, NC, AFR, dan SIL) yang telah mampu mengerjakan soal dengan lancar yaitu berada pada TBKM level 3, namun ada dua subjek yang inisial (MH dan NAA) yang mengerjakan soal dengan cukup lancar yaitu berada pada TBKM level 2. 


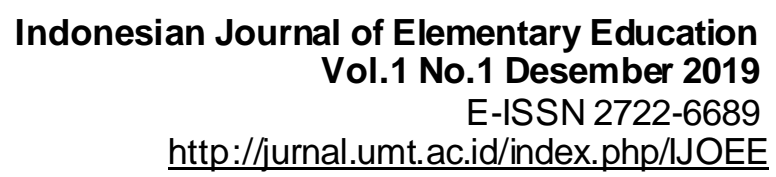

Dengan demikian subjek penelitian telah mampu memecahkan permasalahan dengan lancar. Subjek penelitian lancar dalam menyebutkan informasi yang disediakan dalam soal. Sehingga mereka tidak merasa kesulitan untuk mengerjakan soal dan yakin jawabannya benar. Hal ini dikarenakan mereka telah memiliki pengetahuan yang cukup tentang materi operasi hitung pada pecahan. Jawaban yang diberikan diusahakan lebih dari satu jawaban. Subjek penelitian mengerjakan dengan proses yang benar serta penjelasan yang diberikan cukup lengkap.

Pencapaian indikator berpikir luwes (flexibility) pada soal nomor 2 dimana subjek (KS dan SIL) berada pada kategori TBKM luwes dengan level 3, inisial subjek (NC dan $\mathrm{MH}$ ) berada pada kategori TBKM cukup luwes dengan level 2, dan inisial subjek (AFR dan NAA) berada pada kategori TBKM kurang luwes dengan level 1. Sedangkan pada soal nomor 5 subjek inisial (KS, NC, AFR dan NAA) berada pada TBKM level 3 yaitu luwes, inisial subjek SIL berada pada TBKM level 1 yaitu kurang luwes dan inisial subjek MH berada pada TBKM level 0 yaitu tidak luwes karena tidak menjawab soal yang telah diberikan. Dengan demikian Sebagian subjek sudah mengerti dan telah mencoba untuk memberikan jawaban dengan lebih dari satu cara, meskipun masih banyak yang melakukan kekeliruan dalam proses perhitungannya. Beberapa orang telah mampu menunjukkan hal-hal yang menjadi permasalahan, namun untuk beberapa subjek lain masih belum mengerti betul apa yang menjadi permasalahan dan apa yang dimaksud dalam soal tersebut, sehingga hanya mampu menemukan satu cara dalam menyelesaikan masalah.

Pada indikator berpikir orisinil (orginality) subjek penelitian pada kategori tin ggi hanya mampu berada pada tingkat cukup orisinil. Dimana sebanyak 3 orang (inisial KS, NC dan SIL) telah mampu mengerjakan soal dengan cara cukup orisinil. Dan sebanyak 2 orang (inisial MH dan NAA) yang telah mampu mengerjakan soal dengan cara masih kurang orisinil dengan TBKM level 1, meskipun demikian subjek telah berusaha dan mampu mengerjakan soal permasalahan tersebut. Sedangkan inisial AFR berada pada TBKM level 0 tidak orisinil karena subjek tidak mampu mengerjakan dan men yelesaikan soal pemecahan masalah yang telah diberikan. Subjek penelitian hanya terbias a den gan cara yang mereka telah pelajari. Sehingga kurang bisa memberikan ide yang orisinil untuk memecahkan masalah dengan cara mereka sendiri.

Secara umum indikator berpikir terperinci (elaboration) telah terpenuhi oleh 
subjek inisial (KS dan NC) yang berada pada TBKM level 3 dan menjawab soal pemecahan masalah dengan rinci, subjek inisial (AFR dan NAA) berada pada TBKM level 2 yaitu menjawab soal dengan cukup rinci, dan inisial SIL berada pada TBKM level 1 dengan menjawab soal pemecahan masalah kurang rinci, sedangkan subjek inisial MH tidak menjawab soal pemecahan masalah sehingga berada pada TBKM level 0 tidak rinci. Sebagian subjek penelitian tidak betul-betul detail ketika menjawab soal dengan permasalahan yang telah diberikan, sehingga ketika menjawab kurang teliti dalam perhitungan.

\section{KESIMPULAN DAN SARAN}

Temuan dari penelitian mengenai Analisis Kemampuan Berpikir Kreatif Matematis Siswa dalam Menyelesaikan Soal Pemecahan Masalah telah menjawab rumusan masalah yang disusun peneliti tentang bagaimana kemampuan berpikir kreatif matematis siswa dalam menyelesaikan soal pemecahan masalah pada soal cerita dengan materi pecahan, tingkat kreativitas yang paling dominan adalah kreativitas tingkat 3 . Untuk siswa yang berkemampuan tinggi mencapai kreativitas tingkat 3, yaitu mampu menunjukkan kefasihan dan kebaruan atau kefasihan dan fleksibilitas. Siswa berkemampuan sedang mencapai kreativitas tingkat 2, yaitu mampu menunjukkan kebaruan atau fleksibilitas. Sedangkan siswa berkemampuan rendah atau kurang mencapai kreativitas tingkat 1, hanya mampu menunjukkan kefasihan saja. Dengan demikian, kreativitas tingkat 3 dari beberapa siswa yaitu kefasihan dan fleksibilitas adalah yang sering muncul dalam penelitian.

Beberapa hal ini dapat dijadikan alternatif solusi; guru terlebih dahulu hendaknya mampu menganalisis faktor penyebab dari siswa sendiri maupun yang dimungkinkan dari guru dan faktor lain, tanamkan kepada siswa sifat untuk mampu memotivasi dirin ya sendiri melalui pemberian latihan soal yang bertujuan menggali kemampuan yang mungkin belum muncul, fasilitasi siswa dalam memahami materi pecahan pada soal cerita yang diajarkan dengan kemasan menarik sehingga akan menantang dan melatih siswa untuk dapat berpikir kompleks dan kreatif matematis, tanpa harus terpaku pada rumus-rumus. 


\section{DAFTAR PUSTAKA}

http://jurnal.umt.ac.id/index.php/lJOEE

Abidin, Yunus. (2015). Revitalisasi Penilaian Pembelajaran. Bandung: Refika Aditama.

Arikunto, Suharsimi. (2013). Prosedur Penelitian. Jakarta: Rineka Cipta.

Hartono, Yusuf. (2014). Matematika Strategi Pemecahan Masalah. Yogyakarta: Graha Ilmu

Heruman. (2017). Model Pembelajaran Matematika Di Sekolah Dasar. Bandung: PT Remaja Rosdakarya.

Indarwati, Desi, dkk. (2014). Peningkatan Kemampuan Pemec ahan Masalah Matematika Melalui Penerapan Problem Based Learning Untuk Siswa Kelas V SD. Jurnal Pendidikan, 17-27.

Mairing, Pasini Jackson. (2018). Pemecahan Masalah Matematika. Bandung: Alfabeta.

Moma, La. (2015). Pengembangan Instrumen Kemampuan Berpikir Kreatif Matematis untuk Siswa SMP. Delta-Pi:Jurnal Matematika dan Pendidikan Matematika, 27-41.

Moleong. (2017). Metodologi Penelitian Kualitatif. Bandung: PT Remaja Rosdakarya.

Muhsetyo, Gatot. (2010). Pembelajaran Matematika SD. Jakarta: Universitas Terbuka.

Munandar, Utami. (2017). Mengembangkan Bakat dan Kreativitas Anak Sekolah. Jakarta: PT Gramedia Widiasarana.

Nanan, S. (2017). Metode Penelitian Pendidikan. Bandung: PT Remaja Rosdakarya.

Noer, Hastuti Sri. (2010). Kemampuan Berpikir Kreatif Matematis Apa, Mengapa, dan Bagaimana?

Prosiding Seminar Nasional Penelitian, Pendidikan dan Penerapan MIPA , 521-526.

Ramadhani, Dini dan Nuryanis. (2017). Analisis Kemampuan Berpikir Kreatif Matematis Siswa SD Dalam Menyelesaikan Open-Ended Problem. Jurnal JPSD , 55-62.

Sakti, Indra. (2011). Korelasi Pengetahuan Alat Praktikum Fisika dengan Ke mampuan Psikomotorik Siswa di SMA Negeri q Kota Bengkulu. Jurnal Exacta , 67-76.

Shadiq, F. (2014). Pembelajaran Matematika Cara Meningkatkan Kemampuan Berpikir Siswa. Yogyakarta: Graha Media.

Siswono, Tatag Yuli Eko. (2018). Pembelajaran Matematika Berbasis Pengajuan dan Pemecahan Masalah. Bandung: PT Remaja Rosdakarya. 
http://jurnal.umt.ac.id/index.php/lJOEE

Sugiyono. (2015). Metode Penelitian Pendidikan Pendekatan Kuantitatif, Kualitatif, dan $R \& D$. Bandung: Alfabeta.

Sun, Kheng Peng. (2011). Menikmati Belajar Secara Kreatif. Yogyakarta: Samudra Biru.

Suryadi, Didi. (2012). Membangun Budaya Baru dalam Berpikir Matematika. Bandung: Rizqi Press.

Tasrial, dan Daryanto. (2012). Konsep Pembelajaran Kreatif. Yogyakarta: Gava Media.

Wahyudi, D. (2012). Pemecahan Masalah Matematika. Salatiga: Widya Sari Press.

Wena, Made. (2014). Strategi Pembelajaran Inovatif Kontemporer. Jakarta: Bumi Aksara.

Winarni, Setyo, S. H. (2017). Matematika Untuk PGSD. Bandung: PT Remaja Rosdakarya. 